\title{
CONCEPTUALIZATION OF GROUNDWATER FLOW IN THE EDWARDS AQUIFER THROUGH THE KNIPPA GAP HYDROGEOLOGIC CONSTRICTION, UVALDE COUNTY, TEXAS
}

\author{
Jennifer Adkins \\ 5695 W. Michael Cole Dr., Fayetteville, Arkansas, 72704,USA, jadkins@uark.edu
}

\begin{abstract}
The Balcones Fault Zone Edwards aquifer (Edwards aquifer) is one of the major regional karst aquifers in the United States, with an average withdrawal of 950 million liters per day (L/d). This study focuses on the connection between the Uvalde pool and the San Antonio pool of the Edwards aquifer, west of the San Antonio metropolitan area in Uvalde County, Texas. This area is known as the Knippa Gap and is located north of the community of Knippa. The Knippa Gap is a major zone controlling the flow from the Uvalde pool to the San Antonio pool. The San Antonio pool is the primary source of water for the greater San Antonio water supply. The Knippa Gap is a restriction where the aquifer narrows to a width estimated to be approximately $4 \mathrm{~km}$, is bounded by northeast trending faults of the Balcones Fault Zone on the north, and uplift from the Uvalde salient and igneous intrusive plugs to the south. (Green et al., 2006). The hydrogeology in the Knippa Gap has been a topic of major interest among researchers in this area for numerous years, yet the exact location, nature of boundaries, and karst hydrogeology are not well defined, and the flow through this area is in need of refinement to improve the aquifer water balance.
\end{abstract}

This study integrates recent research by other scientists with field studies conducted during the summer of 2012 as part of an M.S. thesis. This paper is limited to a discussion of the water quality as it relates to the southern flow boundary of the Knippa Gap near the Devils River Trend of the Uvalde salient. Waterquality data constrain a revised conceptual model of the flow and karstification in this critical area of recharge to the San Antonio pool, and provide specific lateral boundaries and vertical karstification zones which are being tested in the more comprehensive M.S. thesis. Although current interpretations are tentative, it appears this conceptual model will be readily convertible into a digital model that can test hypotheses relating a much broader suite of calibration data, including water levels, water budgets, and spring discharges.

\section{Introduction}

The Edwards aquifer, located in south-central Texas (Figure 1), is one of the most prolific artesian aquifers in the world, providing more than 950 million liters of water to more than 2 million people on an average day. In addition, this aquifer is home to more than 40 aquatic subterranean species, several of which are endangered, and one that is threatened (http://www.edwardsaquifer. org/). The Edwards aquifer provides most of the agricultural, industrial, recreational, and domestic water needs throughout its area of occurrence in west-central Texas (Welden and Reeves, 1962; Hamilton et al., 2012).

The artesian zone (confined) of the Edwards aquifer typically occurs at depths ranging from 150 to $300 \mathrm{~m}$ with some depths extending up to $1,000 \mathrm{~m}$. The northsouth extent of the aquifer ranges between 10 to 60 kilometers, and the east- west is approximately 240 kilometers (Figure 1). Recharge to the Edwards aquifer occurs from the capture of surface water originating from the contributing zone (allogenic recharge), direct precipitation on the recharge zone (autogenic recharge), and inter-formational flow from adjoining formations, both above and below the Edwards Limestone. Discharge in the Edwards aquifer most often occurs by spring flow, pumping, and interformational flow to down -gradient aquifers (Green et al., 2012).

Regionally, the structure of the aquifer is exceedingly complex, owing to the extensive faulting associated with the Balcones Fault Zone. The faulting in the Balcones Fault Zone is primarily en echelon normal faulting that is northeast-southwest trending, and is predominantly down to the southeast (Clark, 2003; Barker and Ardis, 1996; Hovorka et al.,2004). The Balcones Fault Zone is 


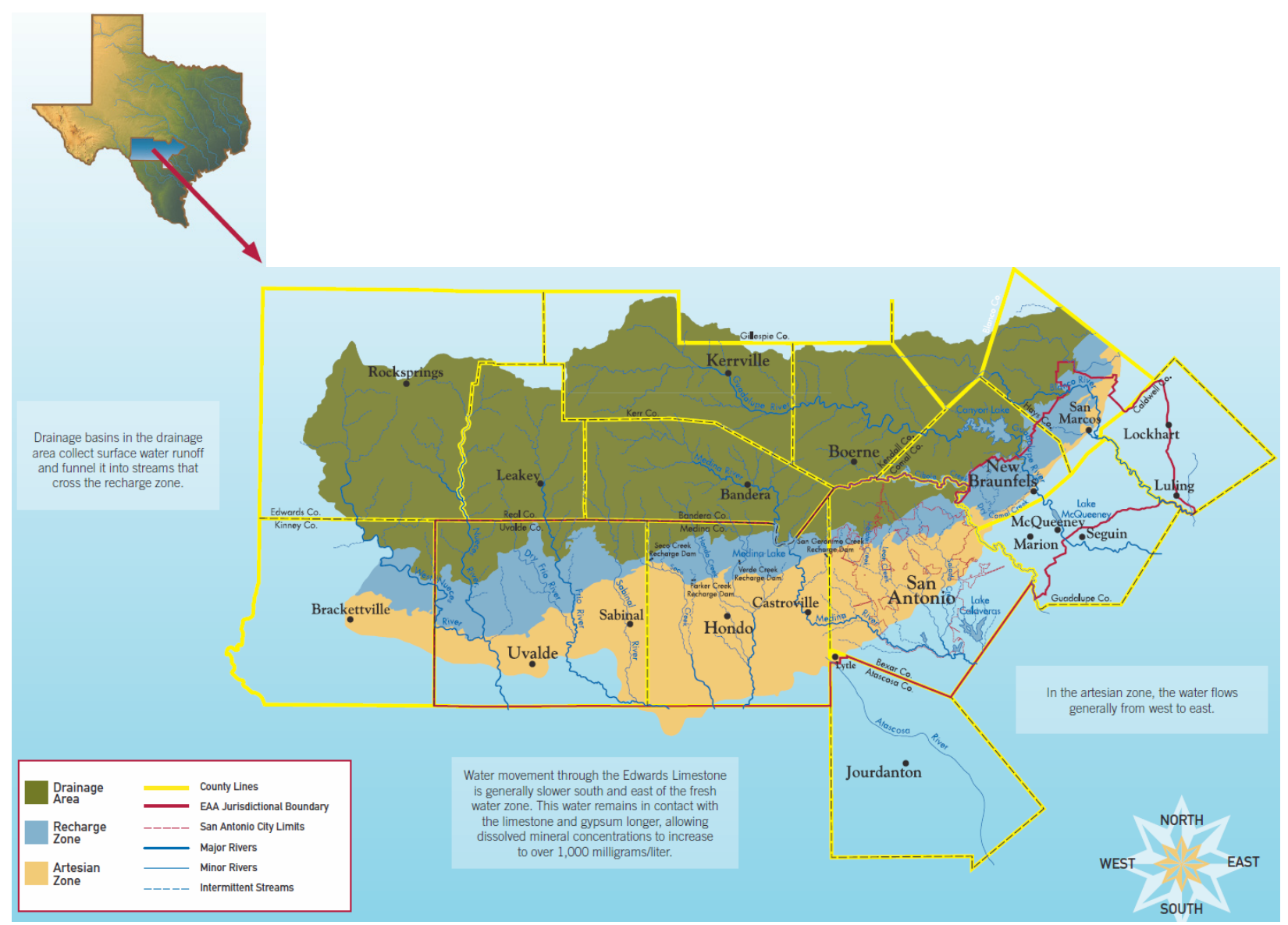

Figure 1. Location of the major hydrogeologic zones of the Edwards aquifer in south-central Texas, by county. The study area of this project is the Knippa Gap in Uvalde County, shown in purple between the towns of Uvalde and Sabinal on the map [Modified from Edwards Aquifer Authority webpage].

thought to delineate the northwestern boundary of the Knippa Gap as a series of faults that have been plugged by low-permeability, fine-grained sediments, and therefore act as no-flow boundaries (Maclay and Land, 1988). South and east of the Knippa Gap, major regional tectonic activity occurred, which includes igneous intrusions and uplift. This event bowed the overlying sediments, including the Edwards Group, uplifting the formations to much shallower depths (Mosher et al., 2006), and resulted in the structural feature known as the Uvalde salient of the Devils River Trend. This feature dips into the Maverick Basin toward the southwest (Figure 2).

Lithologically, the Edwards aquifer in the area of the San Antonio pool comprises as many as 8 members and formations of the Edwards Group, predominantly carbonates and evaporates that were deposited in the latter part of the Early Cretaceous period (Clark, 2003; Hvorka et al., 2004). A pool within an aquifer is a region surrounded by low-permeability zones that restrict dynamic flow out of the region. Most water escapes from the pool by overflowing at low points, such as the Knippa Gap, and springs along the Leona River (Green et al., 2006). In this area of transition in the Knippa Gap, that number decreases from 8 to 3 formations in the Maverick Basin, or 1 formation in the Devils River Trend of the Uvalde salient Figure 3 (Green et al., 2009).

Since deposition, rocks of the Edwards Group have experienced a complex history, including aerial to subaerial exposure, burial (middle Cretaceous), faulting uplift, erosion, and intense karstification (Rose, 1973). In the catchment area of the aquifer (Figure 1), dominant karst processes are epigenic. This means dissolution is produced primarily by descending recharge and horizontal groundwater movement.

However, based on the cave structure and morphological forms such as vertical shafts, scallops, 


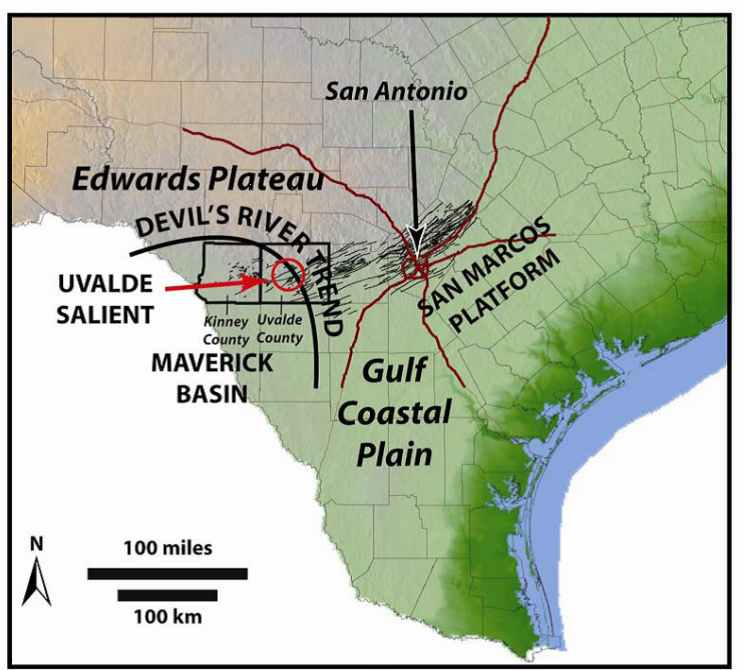

Figure 2. Location of the Devils River Trend, Maverick Basin, Uvalde Salient and the San Marcos Platform [Adapted from Green et al., 2006].

and cupulas, many researchers conclude that hypogenic speleogenesis (deep regional upward flow) has played an important role in the karst development of the Edwards aquifer (Klimchouk, 2007). Regional flow systems in the Edwards aquifer resurge as large springs where groundwater is returned to the surface from depth. Permeability derived by this upward water flow plays an integral part in the aquifer as well as hydrocarbon storage within the rock unit (Schindel et al., 2008).

Hydrogeologically, the Edwards aquifer is separated into three regional zones, the recharge zone, the contributing zone, and the artesian zone (Figure 1). The contributing zone, identified as the drainage area on Figure 1, captures infiltrated precipitation and allows runoff into streams or infiltration to the water table aquifer to occur. This zone is also where contamination of the aquifer is most likely to occur, primarily as a result of shallow water tables, intense karstification, and little to no soil cover. The recharge zone is dominated by vertical faulting of the Balcones Fault Zone, and is the part of the aquifer where major recharge makes its way to the artesian zone. Entryways are predominantly faults of the Balcones fault zone, and major inputs are point and line sources where streams and rivers cut across this zone of faulting. The artesian zone is the southern and easternmost part of the aquifer where water is confined. The confining layers for the Edwards are the Glen Rose Formation below and the Del Rio Clay above (Figure 3).

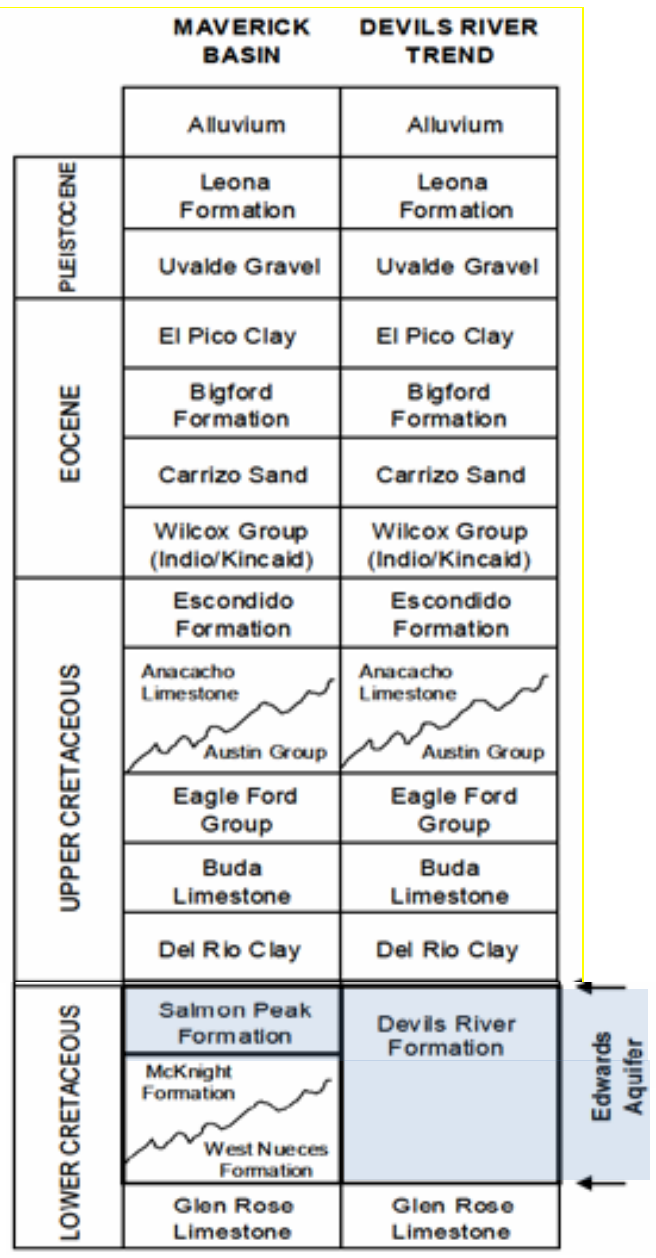

Figure 3. Stratigraphic column from southwest to northeast across Uvalde County in the study area, Knippa Gap. Karstified focused flow zones of the Edwards are shown in blue [Modified from Green, 2009].

\section{Problem Statement}

The Edwards aquifer has been intensively studied, but many important questions remain unanswered. One major question deals with groundwater flow through the Uvalde County area (Figure 1) known as the Knippa Gap (Figure 4). This part of the Edwards aquifer represents an overflow zone approximately $4 \mathrm{~km}$ wide bounded by northeast trending faults of the Balcones Fault Zone. Water discharges from the Uvalde Pool on the west into the San Antonio Pool in the east. Southeast of the Knippa Gap uplift was caused by igneous intrusions forming the Uvalde salient structure, resulting in little or no flow and minimal well yields in this part of the aquiferessentially a zone of no flow along the southeastern edge of the Uvalde Pool (Green, 2006). The amount of groundwater flow that discharges through the Knippa 
Gap is not well constrained, in part because a significant portion of outflow from the Uvalde pool discharges to the south through subcrops to the Leona gravels. More refined flow estimates, along with a better understanding of how the Knippa Gap functions, would greatly refine the water budget for the San Antonio Pool and more accurately determine flow boundaries and budgets for the Uvalde pool.

\section{Objective and Scope}

The object of this report is to refine the conceptual model of flow in the Edwards aquifer through a flow constriction in Uvalde County, Texas, known as the Knippa Gap. Discussion here is limited to the factors related to water quality; however, this paper is only a small part of a much broader M.S. study of the karst hydrogeology of the region.

\section{Study Area}

The study area is shown in the shaded region of Figure 4. An expanded but secondary area of interest surrounds the main study area, encompassing contiguous portions of the integrated Edwards aquifer flow system. The Edwards aquifer in Uvalde County is predominantly composed of Lower Cretaceous carbonate (dolomitic limestone) of the Devils River Formation within the Devils River trend in the northeast, transitioning into the West Nueces, McKnight, and Salmon Peak Formations in the Maverick Basin in the southwest.

These carbonate rocks were formed in evolving environments that ranged across a variety of tectonic and depositional conditions. The Devils River Trend was an open, shallow-marine environment of high current energy, whereas the West Nueces, McKnight, and Salmon Peak Formations were restricted to open marine, deep-basinal environments (see Rose, 1973). The upper units of the Devils River Trend along with the upper unit of the Salmon Peak Formation are the most prolific water bearing units in the study area.

Throughout the study area there are numerous Upper Cretaceous or Lower Tertiary igneous rocks that intrude through the stratigraphic units composing the Edwards aquifer (Clark, 2003). Uvalde County contains multiple minor groundwater resources from a thick sequence of sedimentary rocks. The Edwards is by far the most significant of these aquifers, spanning the central portion of the county from west to east. The Buda, Austin Chalk, gravels of the Leona River, and the Trinity aquifers are the major secondary aquifers that are present in Uvalde County. (Green, 2009) Several noteworthy structural features have been studied throughout Uvalde County, such as the Uvalde salient (resulting from crustal uplift, faulting, and igneous activity that elevates the Edwards aquifer to the surface across the central region of the county), and the Balcones fault zone (a tensional structure area aligned southwest to northeast across the study area). Preliminary interpretation of the Knippa Gap indicates that it is a structural feature that acts as a barrier, separating the Uvalde pool from the San Antonio pool under Medina, Bexar, and Comal Counties. It is described as being a narrow opening in an extensive system of barrier faults. (McClay and Land, 1988) Although $2.4 \times 10^{11}$ liters (200,000 acrefeet) are estimated to flow through the Knippa Gap annually, the constriction causes water levels to build up in the Uvalde pool. Green et al. (2006; 2009a; 2009b) conclude that the Uvalde salient has several prominent structural high points that constrict the groundwater flow through "topographic saddles" between the high points. They also note the large amounts of recharge from the Frio and Dry Frio Rivers that are contributing to the groundwater flow in the region, and conclude that the Knippa Gap flow constriction and the incoming recharge cause a damming affect for the groundwater up-gradient and west of the gap (Green et al., 2006). Water use in the east is significant, owing to close proximity to the cities of San Antonio, New Braunfels, and San Marcos. Recharge of the aquifer is greatly impacted by periodic droughts, and the flow of the recharge from west to east is significantly constricted in the area of Knippa Gap.

\section{Methods and Approach}

The hydrogeology and eleven wells described herein (Table 1, Figures 4, 5, and 7) were sampled for field parameters and major-element geochemistry to evaluate areal distribution of water quality and to redefine flow boundaries in the conceptual model.

The conceptual model (Figure 7) incorporates samples contiguous to the study area, displaying the major ion compositions of these samples. These data allow visualization of geochemically related waters, and the determination of flow paths. These data also facilitate an understanding of the geochemical processes acting in the flow system, and help to characterize evolution of water type in the aquifer. These should 
Table 1. Selected water quality and dissolved constituents in water from wells in the study area. QW Site number is referenced to Figure 4. Chemical parameters are in $\mathrm{mg} / \mathrm{L}$.

[QW, water quality; TDS, total dissolved solids, in $\mathrm{mg} / \mathrm{L}$; Cond, specific conductance, in $\mu \mathrm{S} / \mathrm{cm}$ ]

\begin{tabular}{|c|c|c|c|c|c|c|c|c|c|c|c|c|c|}
\hline $\begin{array}{l}\text { QW } \\
\text { Site }\end{array}$ & Well ID & Date & TDS & $\begin{array}{l}\text { Temp } \\
{ }^{\circ} \mathrm{C}\end{array}$ & Cond & pH & $\mathbf{C a}^{+2}$ & $\mathbf{M g}^{+2}$ & $\mathbf{N a}^{+}$ & $\mathbf{K}^{+}$ & ALK & $\mathrm{Cl}^{-}$ & $\mathrm{SO}_{4}^{-2}$ \\
\hline 1 & $\begin{array}{l}\text { YP-69-43- } \\
606\end{array}$ & $6 / 18 / 2012$ & 237 & 23.5 & 481 & 7.20 & 82.1 & 10.4 & 10.8 & 1.07 & 203 & 19.9 & 12.3 \\
\hline 2 & 6943919 & $6 / 18 / 2012$ & 1210 & 26.6 & 1605 & 6.98 & 277 & 27 & 28.1 & 2.91 & 169 & 72.9 & 630 \\
\hline 3 & 69433JY & $6 / 18 / 2012$ & 260 & 23.6 & 471 & 7.25 & 79.9 & 10.3 & 9.93 & 0.974 & 188 & 20.6 & 11 \\
\hline 4 & 6943903 & $6 / 18 / 2012$ & 340 & 23.9 & 477 & 7.49 & 86.8 & 9.28 & 11.1 & 1.1 & 203 & 20.2 & 11.7 \\
\hline 5 & $\begin{array}{l}6943701- \\
W 101-561\end{array}$ & $6 / 18 / 2012$ & 877 & 24.7 & 1274 & 7.24 & 168 & 21.9 & 77.8 & 5.62 & 241 & 158 & 196 \\
\hline 6 & 6943803 & $6 / 18 / 2012$ & 353 & 24 & 502 & 7.27 & 85.3 & 8.33 & 11.7 & 1.03 & 206 & 23.8 & 12 \\
\hline 7 & $\begin{array}{l}\text { 69439MB } \\
\text { W101-594 }\end{array}$ & $6 / 19 / 2012$ & 376 & 24.7 & 701 & 7.16 & 93.1 & 17.8 & 25.6 & 2.36 & 200 & 55.5 & 55.9 \\
\hline 8 & 69436JS & $6 / 19 / 2012$ & 238 & 25.1 & 428 & 7.36 & 63.9 & 13 & 6.9 & 0.097 & 179 & 14.1 & 11.5 \\
\hline 9 & 6942606 & $6 / 19 / 2012$ & 303 & 23.6 & 502 & 7.21 & 80.3 & 8.22 & 11.7 & 0.973 & 199 & 33.5 & 10.6 \\
\hline 10 & $69-50-3 \mathrm{BR}$ & $6 / 19 / 2012$ & 344 & 23.2 & 601 & 7.37 & 88.8 & 9.19 & 21.3 & 0.962 & 212 & 42.8 & 18 \\
\hline 11 & $69-43-103$ & $6 / 19 / 2012$ & 365 & 23.8 & 448 & 7.19 & 93.2 & 9.57 & 24 & 1.09 & 215 & 51.1 & 19.2 \\
\hline
\end{tabular}

not be used alone to delineate the gap, but they are a good conceptual start to test alternative hypotheses. Considering the complex faulting in the immediate area, they are consistent with a structural basis for constructing the boundaries of the Knippa Gap.

\section{Results}

Table 1 shows the water quality and dissolved constituents in water from wells located within the study area. The Well ID in Table1 is referenced to Figure 5, and the QW Sites to Figure 7. Figure 5 includes 2 sample sites (QW site 69439JA, and 6950310) that were excluded from Table 1 owing to cation/anion imbalances outside the range of $5 \%$ error.

Table1 and Figures 6 and 7 indicate the presence of high sulfate and high chloride waters with higher specific conductance (701 to $1605 \mathrm{mS} / \mathrm{cm}$ ) and higher temperatures (26.6 to $24.7^{\circ} \mathrm{C}$ ) that occur in wells within the Uvalde salient (QW Sites 2, 5, 7). Waters west (QW Sites 4, 6, 8, 9, 10, and 11) and east (QW Sites 3 and 1) of the salient are calcium-magnesium bicarbonate waters with lower dissolved solids (428 to $601 \mu \mathrm{S} / \mathrm{cm}$ ) and slightly lower temperatures $\left(23.5\right.$ to $25.1{ }^{\circ} \mathrm{C}$ ). QW Site 8 represents the least mineralized of all wells sampled, not only in terms of specific conductance, but also in terms of the lowest concentrations of dissolved chloride and dissolved sulfate. Various degrees of mixing of waters from different sources are present in these latter wells, reflecting variations in lithologies along the flow path.

\section{Conclusions}

The conceptual model (Figure 7) allows visualization of water type and major flow directions that are 


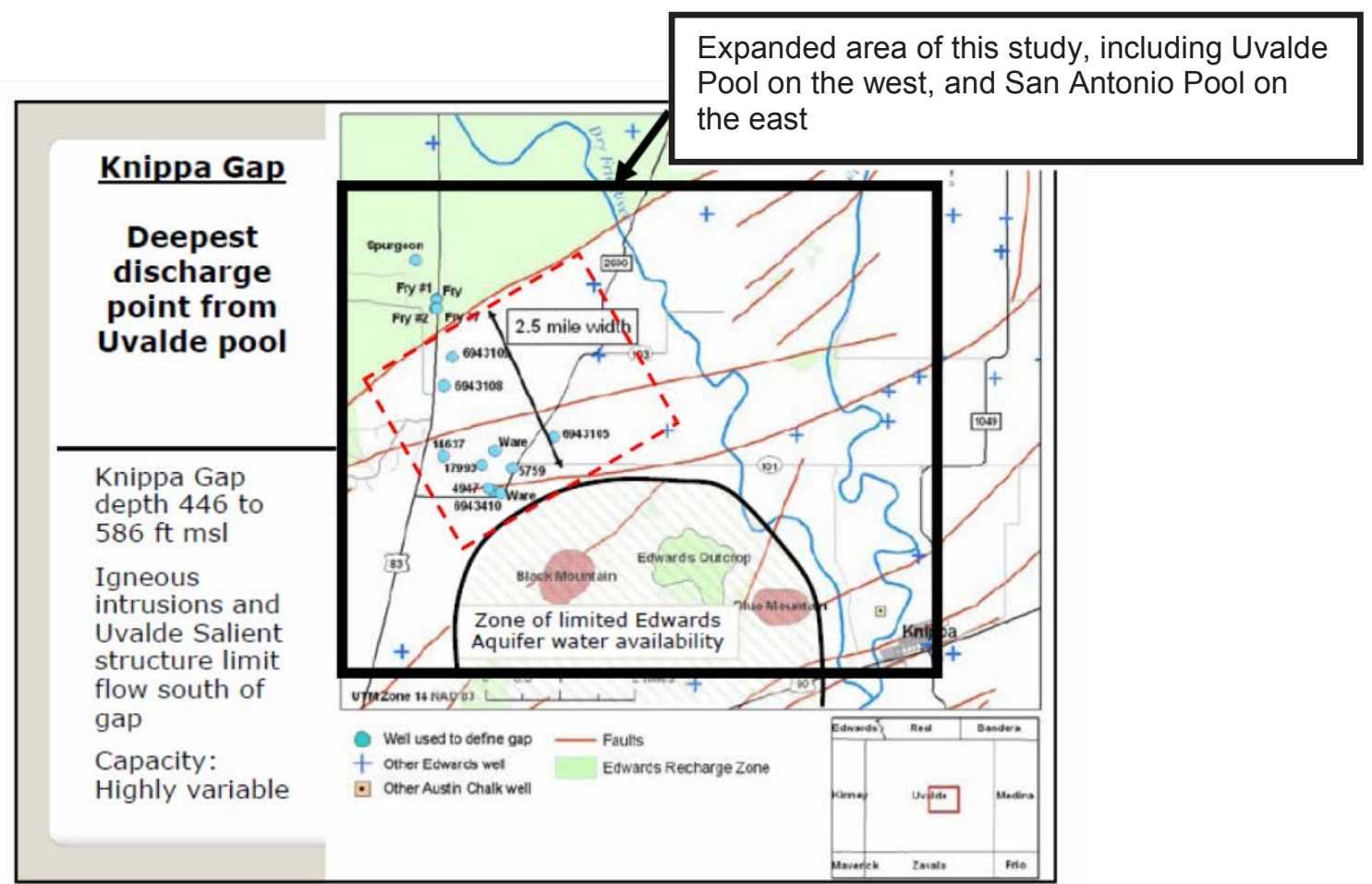

Figure 4. Location of key components of the Knippa Gap, the expanded study area, and other relevant hydrogeologic features in Uvalde County [Modified from Green, 2009].

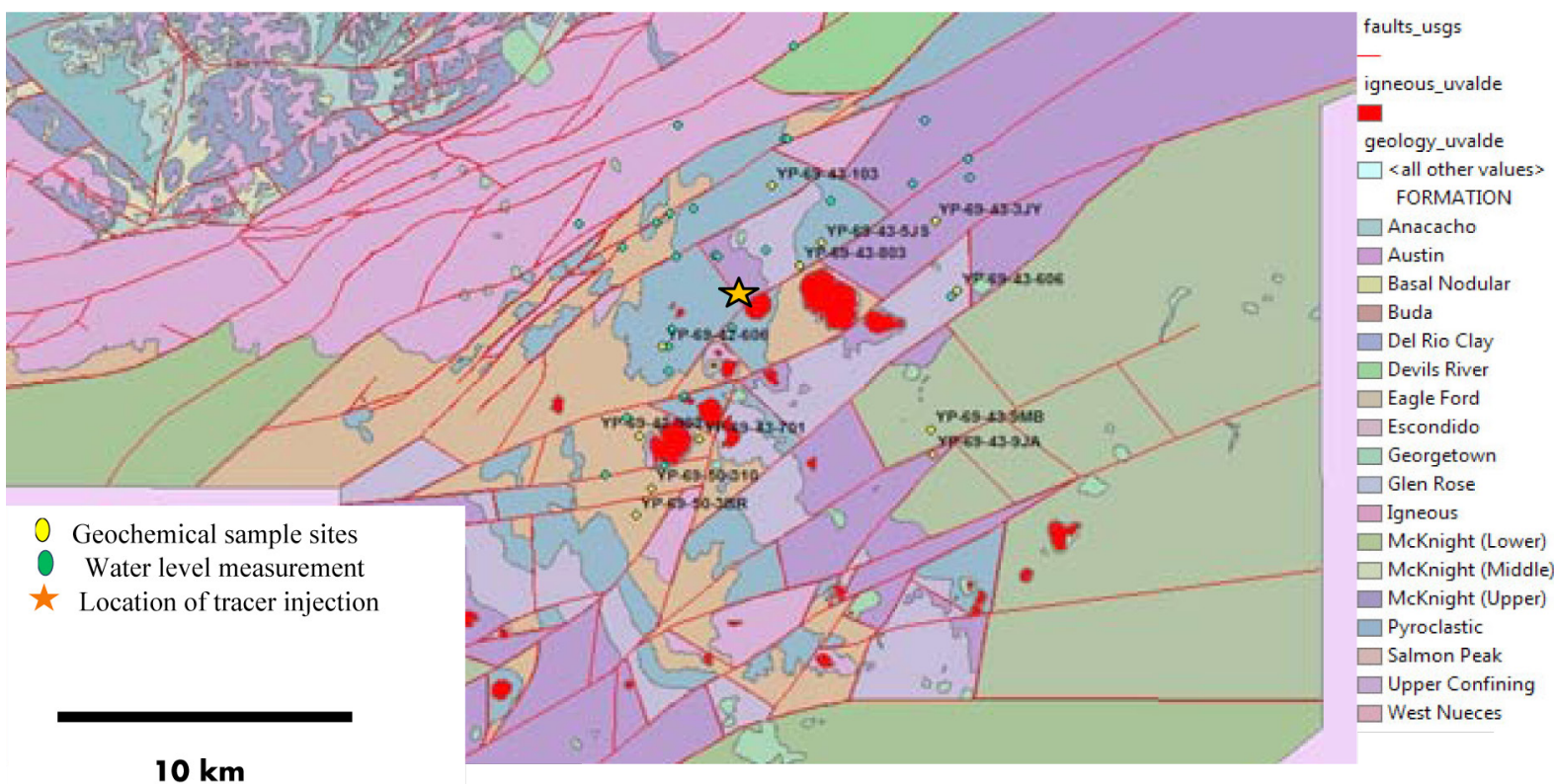

Figure 5. Geology of the Edwards aquifer in the study area, including areal geology, faulting associated with the Balcones fault zone (red lines), exposures of igneous intrusives associated with the Devils River Trend of the Uvalde salient (in red), and sampling sites of wells used to measure water levels and collect groundwater samples. The numbers refer to the sampled wells discussed in Table 1. [Map modified from multiple sources, including Clark, 2003; Green, 2006, and personal communications with Vic Hilderbran, Uvalde County Water Conservation District and Rob Esquilin, Edwards Aquifer Authority]. 
superimposed on Figure 5, (which includes the Balcones Fault Zone and outcrops of intrusive igneous rocks that roughly define the Uvalde salient), defines likely flow boundaries for the Knippa Gap. Piper (Figure 6) and Stiff(Figure 7) diagrams from sites designated as Knippa Gap wells plot within the carbonate dissolution field, and have specific conductance values that are generally in the range of $400-500 \mathrm{mS} / \mathrm{cm}$, and temperatures in the range of 23 to $24{ }^{\circ} \mathrm{C}$. QW Site 8 , the least mineralized well sampled, is the only exception to the temperature range listed, with a value of $25^{\circ} \mathrm{C}$. In addition to flow boundaries and flow directions, Figure 7 also indicates the approximate location of the subsurface overflow from the Uvalde Pool to the Leona gravels.

Stiff diagrams for QW Site 2 is thought to lie near the bad water line, an arbitrary line defined by total dissolved solids greater than 1,000 mg/l and defining the southern boundary the freshwater portions of the Edwards aquifer. Increased mineralization is a result in increased contact with gypsum and has more limited development of

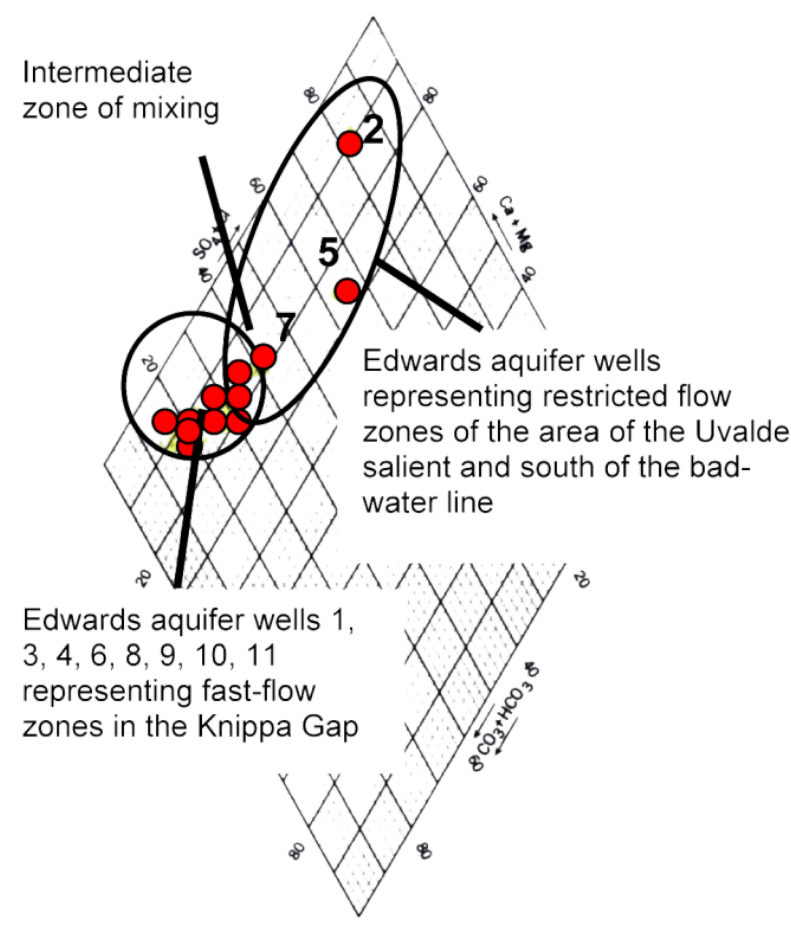

Figure 6. Piper diagram of groundwater in the study area showing water quality types ranging from waters within the Knippa Gap (within black circle) to waters derived from mixing of high sulfate and chloride waters associated with residual evaporites in less dynamic flow zones (see wells 2, 5, and 7 in Table 1). secondary permeability than the freshwater portions of the aquifer. These factors result in greater salinity levels and distinctive Stiff diagrams. The conceptual model (Figure 7) shows that (QW) sites 5 and 7 plot along a mixing line of meteoric water and down gradient water similar in chemical composition to well 2. As indicated by the curved blue lines on the model, these QW sites have mixing components that are inconsistent with focused flow through the Knippa Gap, and do not lie in the main flow zone of the Edwards aquifer. The high specific-conductance waters with higher concentrations of chloride and sulfate cannot be rectified with rapid groundwater flow zones and major karst development. Most of the wells with these attributes overlie the Uvalde salient, and because of the structural uplift, the aquifers are closer to surface-water inputs. It is speculated that this proximity may contribute to slightly higher temperatures although this needs to be investigated further. Well yields in this area are also consistent with much less flow (and dissolution of the highly soluble evaporates) through this part of the aquifer. Well 11 is an exception to this, but inasmuch as it lies on the boundary of this study and its explanation at this point is not obvious.

Data from the remaining QW sites have Stiff diagrams representing the fresh fast-flow zones with dissolution as the main geochemical process. These QW sites plot within the carbonate dissolution field of the Piper diagram (Figure 6) as well, and have calculated TDS values ranging from $228 \mathrm{mg} / \mathrm{L}$ to $353 \mathrm{mg} / \mathrm{L}$ further supporting the evidence for the constricted flow path of the Knippa Gap.

\section{Future Work}

In addition to the geochemical analysis discussed in this paper, the larger M.S. study will incorporate the compilation of a complete table of wells, geophysical wireline $\operatorname{logs}$, water-quality analyses, water-levels, well yields, driller's records, tracing studies, and aquifer tests within the study area. The completed table of wells represents sites with multiple names and aliases, and will aid in future investigations for cross-referencing data, most of which are not in accessible digital format. The table will involve historic published well data, and unpublished records from drillers, water managers, and hydrogeologists in the area, and will be supplemented by field inventories of wells which will be conducted during the summer of 2013. 


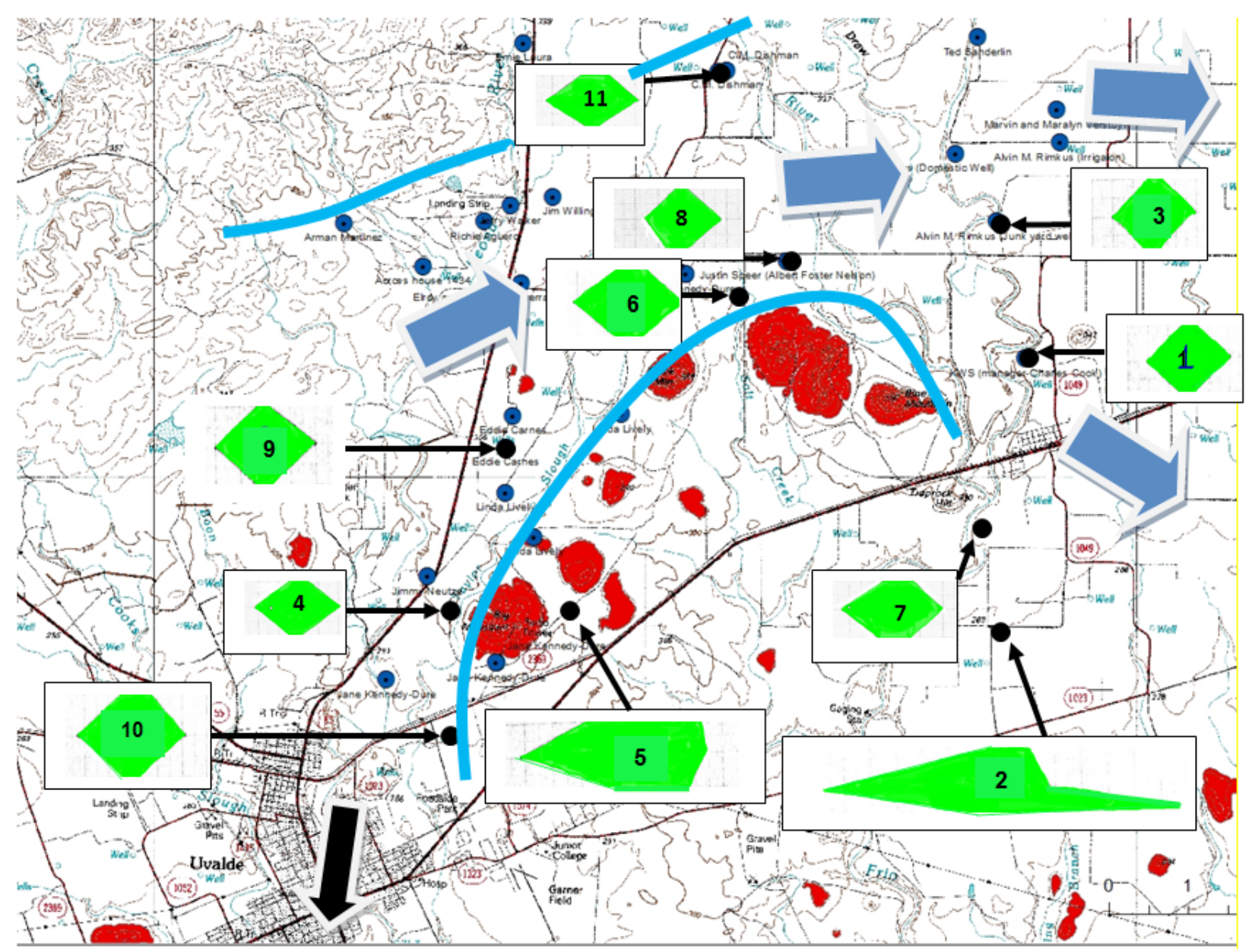

Figure 7. Conceptual model of the Edwards aquifer in the study area, showing Stiff diagrams that reflect major element concentrations dissolved in groundwater (in green), approximate locations of boundaries of flow through the Knippa Gap (curved blue lines), major flow directions through the Knippa Gap constriction (blue arrows), subsurface overflow from the Uvalde Pool to the Leona gravels (black arrow), and exposures of igneous intrusives associated with the Devils River Trend of the Uvalde salient (in red). Sampling sites of wells for which chemical analyses are reported are shown by black dots; the numbers refer to the sampled wells discussed in Table 1 .

A synoptic potentiometric map of the study area will also be assembled. This map will utilize waterlevel data collected from the field during low-stage conditions during the summer of 2012. This effort will incorporate historical water-level data collected by the Edwards Aquifer Authority (EAA), and the results will be used to evaluate potential boundaries, assess variability of aquifer hydraulic properties, and indicate flow directions.

A hydrostratigraphic analysis, incorporating a conceptual model of the Knippa Gap based on drilling and wireline logs, will be helpful to redefine placement of faults (flow boundaries), aid in determining physical constraints and boundaries within the Knippa Gap and improve characterization of the depth of karstification within the study area.

A final assessment in this study should be a tracer test in the study area to evaluate groundwater flow velocities and directionality. A proposed injection site is a sinkhole located very near the southern flow boundary associated with the Uvalde salient (star on Figure 5). Tracer testing is one of the most effective ways of quantifying groundwater movement in karst aquifers, and will provide empirical data that will aid in the determination of the groundwater flowpaths, velocities, dispersion, storage, and dilution components for this region (Schindel et al., 2008). 


\section{Acknowledgments}

I would like to acknowledge Mr. Vic Hilderbran, general manager for the Uvalde County Underground Water Conservation District, for all the help he gave me throughout this project. The depth and breadth of his knowledge about Uvalde County groundwater was outstanding, and he shared his knowledge with me freely. I am truly grateful to him for his assistance.

I also would like to thank Dr. Ron Green and Paul Bertetti of the Southwest Research Institute for providing me with an internship, for guidance, and for encouragement throughout the summer. Their insight was invaluable.

Geary Schindel, Chief Technical Officer for the Edwards Aquifer Authority, not only provided me with an internship and invaluable geochemical and hydrogeologic insight, but he made resources and personnel available to assist in this endeavor. The staff of the Edwards Aquifer Authority, especially Rob Esquilin, Mark Hamilton, Marcus Gary, and Steve Johnson were incredibly generous in sharing their knowledge and data from the Edwards aquifer.

Finally, I would like to thank all the well owners in Uvalde County who allowed me access to their property and facilitated sampling and measuring hydrogeologic parameters of their wells. I know their water is precious to them, and I thank them for trusting me and facilitating my study.

\section{References}

Barker, R.A., and Ardis, A.F., 1996, Hydrogeologic framework of the Edwards-Trinity aquifer system, West-Central Texas: U.S. Geological Survey Professional Paper 1421-B, 61 p.

Clark, A. K., 2003, Geologic framework and hydrogeologic characteristics of the Edwards aquifer, Uvalde County, Texas: U.S. Geological Survey, Water Resources Investigations Report 2003-4010, 17 p.

Dickinson, William R., Gehrels George E., Stern, Robert J., 2010, Late Triassic Texas uplift preceding Jurassic opening of the Gulf of Mexico: Evidence from $\mathrm{U}-\mathrm{Pb}$ ages of detrital zircons. Geological Society of America

Ferrill, David A., Sims, Darrell W., Franklin Nathan, Morris, Alan P., Waiting, Deborah J.,2004, Structural Controls on the Edwards Aquifer/Trinity Aquifer interface in the Helotes quadrangle, Texas. Southwest Research Institute, San Antonio, TX 78238-5166 Department of Earth and Environmental Science, University of Texas at San Antonio.
Ferrill, D. A., and Morris, A. P., 2003, Dilatational normal faults: Journal of Structural Geology, v. 25, p. 183-196.

Fetter C.W. 2001 Applied Hydrogeology (Fourth Edition), Prentice Hall Inc.

Green, R.T., Beretti, F.P., Franklin, N.M., Ferrill D.A., Klar R.V., Morris, A.P., 2006, Evaluation of the Edwards Aquifer in Kinney and Uvalde Counties, Texas. Southwest Research Institute. Conducted for the Edwards Aquifer Authority.

Green, R.T., Bertetti, F.P., McGinnis, Ronald., 2009, Analysis of the Water Resources of the Area Centered Within and Near Uvalde and Zavala Counties and Review of a Report on a Potential Well Field and Pipeline in Uvalde County, Texas Final Report Prepared for City of Uvalde and Wintergarden Groundwater Conservation District Prepared by Geosciences and Engineering Division Southwest Research Institute, SWRI Project No. 20-14842

Green, Ronald. T, Beretti, Paul. F, McGinnis., 2009, Investigating the Secondary Aquifers of the Uvalde County Underground water Conservation District Final Report. Geosciences and Engineering Division Southwest Research Institute.

Green, R.T., Beretti, F.P., McGinnis, Ronald., Prikryl James., 2012, Measure Floodplain Hydraulics of Seco Creek and Medina River where They Overlie the Edwards Aquifer, Final report. Geosciences and Engineering Division Southwest Research Institute.

Hamilton, J.M., Johnson, Steve., Esquilin, Roberto., Burgoon, Chandal., Luevano, Gizelle., Gregory, David., Mireles, Jesse., Gloyd, Ron., Schindel, M. G., 2011, Edwards Aquifer Authority Hydrologic Data Report for 2010.

Hovorka, S. D., Dutton, A. R., Ruppel, S. C., and Yeh, J. S., 1996, Edwards aquifer ground-water resources: geologic controls on porosity development in platform carbonates, South Texas: The University of Texas at Austin, Bureau of Economic Geology Report of Investigations No. 238, 75 p.

Hovorka, S. D., and Mace, R. E., 1997, Interplay of karst, fractures, and permeability in the Cretaceous Edwards aquifer: analogs for fractured carbonate reservoirs: Society of Petroleum Engineers Annual Conference, Geological Field Trip Guidebook, 35 p.

Hovorka, S. D., Mace, R. E., and Collins. E.W., 1998, Permeability structure of the Edwards Aquifer, south Texas - implications for aquifer management: The University of Texas at Austin, Bureau of Economic Geology Report of Investigations No. 250 
Hovorka, S.D., Thandar Phu, J. P. Nicot., Lindley, Adrien., 2004, Refining the Conceptual Model for Flow in the Edwards Aquifer-Characterizing the Role of Fractures and Conduits in the Balcones Fault Zone Segment: Final Contract, Bureau of Economic Geology.

Klimchouk, A., 2007, Hypogene Speleogenesis: Hydrogeological and Morphogenetic Perspective. Special Paper no. 1, National Cave and Karst Research Institute, Carlsbad, NM, 106 pp.

Maclay, R.W., and Land, L.F., 1988, Simulation of flow in the Edwards aquifer, San Antonio region, Texas, and refinement of storage and flow concepts: U.S. Geological Survey Water-Supply Paper 2336-A, 48 p.

Painter, Scott., Jiang, Yefang, Woodbury, Allan., 2002, Edwards aquifer parameter estimation project final report: Southwest Research Institute, variably paginated.

Palmer, A. N., 1991, Origin and morphology of limestone caves: Geological Society of America Bulletin, v. 103.

Rose, P.R., 1972, Edwards Group, surface and subsurface, central Texas. Bureau of Economic Geology Report of Investigations 74:1-198.

Schindel, G. M., Johnson, S. B., Worthington, S. R. H., Alexander, E. C., Jr., Alexander,

Scott., Schnitz, Lewis., 2002, Groundwater chemistry changes during a recharge event in the karstic Edwards Aquifer, San Antonio, TX, Geologicial

Society of America Abstracts with Program. Available from: http:/gsa.confex.com/gsa/2002AM/ finalprogram/abstract 44210.htm

Schindel, G.M., Johnson, Steven.,Alexander, E. Calvin., 2008, Hypogene processes in the Edwards aquifer in South-Central Texas, a new conceptual model to explain squifer dynamics: Adapted from oral presentation at AAPG Annual Convention, San Antonio, TX, Search and Discovery Article \#80019.

Schultz, A. L., 1994, Review and update of the position of the Edwards aquifer freshwater/saline-water interface from Uvalde to Kyle, Texas: Edwards Underground Water District Report 94-05.

Smith, Brian A., Hunt, Brian B., Schindel, M. Geary., 2005, Groundwater Flow in the Edwards Aquifer: Comparison of Groundwater Modeling and Dye Trace Results.

Stanton. G.P., Processes and Controls Affecting Anisotropic Flow in the Boone- St. Joe Aquifer In Northwestern Arkansas: unpublished M.S. thesis, University of Arkansas, Fayetteville.

Veni, George., 2009, The Great Plains, in Palmer, A.N., and Palmer, M.V., eds., Caves and Karst of the USA: National Speleological Society, Inc., p.200-210.
Welder, A.F., and Reeves, D.R., 1962, Geology and Ground-Water resources of Uvalde County, Texas: U.S. Geological Survey Bulletin 6212.

Williams, John, 2003, Borehole geophysics for investigation of ground-water contamination in fractured bedrock: U.S. Geologic Survey, Troy, New York.

Young, S.C., Doherty, J., Budge, R., Deeds, N., 2009, Application of PEST to recalibrate the groundwater availability model for the Edwards-Trinity (Plateau) and Pecos Valley Aquifers - DRAFT. Contract report for the Texas Water Development Board by URS Corporation, Watermark Numerical Pty, Ltd, and Intera Inc. 